This is an accepted manuscript of a book chapter by Kamil Całus and Marcin Kosienkowski, "Relations between Moldova and the European Union," in The European Union and its eastern neighbourhood: Europeanisation and its twenty-first-century contradictions, ed. Paul Flenley and Michael Mannin (Manchester: Manchester University Press, 2018), 99-113, DOI: $10.7765 / 9781526109118.00017$

Kamil Całus

Centre for Eastern Studies (OSW), Warsaw

Marcin Kosienkowski

The John Paul II Catholic University of Lublin

\title{
Relations between Moldova and the European Union
}

\begin{abstract}
This chapter examines relations between Moldova and the European Union since the beginning of the 1990s. What is important for these relationships is that Moldova has expressed the intention of joining the EU since the second half of the 1990s. However, despite its pro-European inclinations, it can be defined as a country that is torn between the West and the East. On the one hand, Moldova is a country with linguistic, cultural and historical ties with Romania, a Latin country which has been a member of the EU since 2007. On the other hand, it is a country with strong links with its Soviet past and Russia that perceives the whole post-Soviet area as its sphere of influences. This chapter traces the evolution of relations between Moldova and the EU: from the strangers in the 1990s to the new neighbours in the 2000 s to the (alleged) partners in the 2010s. In each of these periods motivations and obstacles to cooperation between Moldova's governments and the EU as well as the attitudes of the Moldovan population toward European integration are analysed. A balance of cooperation is also presented.
\end{abstract}

Keywords: Moldova, European Union, European integration, Russia, Transnistria 


\section{Introduction}

The idea of cooperation with the European Union has been, in principle, promoted by Moldovan governments since achieving independence from the Soviet Union in 1991, while its integration aspirations were announced in the second half of the 1990s. Interestingly, European aspirations were expressed by the communists who ruled Moldova for most of the 2000s and the political elites who came to power in 2009 have made integration with the EU their top priority.

However, despite its European inclinations, Moldova can be defined as a country that is torn between West and East, in effect, an 'in-betweener' as already indicated in this volume. On the one hand, it is a country with Latin roots, namely its Romanian language, Romanian culture, and historical ties with Romania, ${ }^{1}$ which has been a member of the EU since 2007. On the other hand, Moldova is a country with strong links to its Soviet past and Russia, which perceives the whole post-Soviet area as its sphere of influence. Key elements of this are: an evident Soviet mentality and nostalgia, economic dependency on Russia, Russianspeaking minorities constituting 20-30 per cent of Moldova's ('right-bank') population, and the existence of the Russian-oriented breakaway region of Transnistria where Russian troops are stationed. All these affect and complicate the process of Moldova's Europeanisation that is understood here as the development of cooperation with the European Union including, eventually, meeting the criteria for greater integration as outlined by the EU (EU-isation).

This chapter seeks to analyse the development of Moldova-European Union relations since the beginning of the 1990s. It analyses motivations and obstacles to cooperation between Moldova's governments and the EU, as well as the attitudes of the Moldovan population toward Europeanisation. The chapter is divided into three sections concerning consecutive decades - the 1990s, the 2000s and the 2010s - marked by changes of Moldovan governments with their own agendas towards European integration and by growing involvement of the EU in Moldova.

\footnotetext{
${ }^{1}$ Until the nineteenth century the territory of present-day Moldova, located on the right bank of the Dniester River (Bessarabia), constituted the eastern part of the Principality of Moldavia which, together with the Principality of Wallachia made up Romania in the second half of that century. Moldova was a part of Romania during 1918-40 and 1941-44.
} 


\section{The 1990s: the strangers}

Following the disintegration of the Soviet Union, the EU decided to establish and define relations with the newly independent states. However, the EU turned out to be reluctant to work out an appropriate agreement with Moldova. This pushed the Moldovan authorities into launching diplomatic efforts in 1993/94 to start negotiations. A Partnership and Cooperation Agreement (PCA) was signed by the parties in November 1994 (Chirila, 2002: 37-42). It was seen by Moldova as a first step toward joining the EU, which was identified, for the first time, as one of its main external policy aims in the 1995 Moldovan Foreign Policy Concept (Conceptia politicii externe a Republicii Moldova, 1995). Additionally, the EU and Moldova decided that provisions on trade would be applied even before ratification of the PCA.

The idea of European integration appeared more frequently in Moldova's official political discourse in the late 1990s. Its integration aspirations were expressed for the first time to European officials by President-elect Petru Lucinschi in December 1996. His government initially pursued the idea of becoming an associate member of the EU, but this met with a cold reaction from the EU which put primary emphasis on implementation of the PCA that had only just entered into force in 1998 (Chirila, 2002: 53-55). From 1998, Moldovan governments continued to pay attention to European integration in their programmes, maintaining it as a strategic objective (Klipii, 2002: 9-26). Moreover, since the launch of the Stability Pact for South Eastern Europe in 1999, the Moldovan authorities made efforts to join this new EU initiative. They hoped that joining the Balkan group of potential EU candidates would provide Moldova with a clear perspective of EU membership (Ungureanu, 2002: 68-79). However, an Eastern orientation of Moldovan foreign policy was not abandoned.

Moldova developed its relations with the EU as part of its policy of achieving broad recognition of its newly established independence and strengthening its statehood. Furthermore, it wanted, to some extent, to balance Russia's dominance in the region. Certainly, its Latinity favoured the idea of cooperation with the West. An important stimulus to Moldova's orientation to the EU came from the former Soviet satellites of Central and Eastern Europe, which had commenced the path towards full integration with the EU. This was especially true of neighbouring Romania. Unlike Russia at the time, the EU attracted Moldova, the poorest state in Europe, with its economic wealth. Moldovan political elites counted on reviving their shaky economy with immediate European development assistance which accounted for $€ 147.7$ million in the 1990s and rapid development of trade relations 
(Löwenhardt et al., 2001: 617-620). The latter turned out to be an urgent priority when Moldova's Commonwealth of Independent States (CIS) oriented economy was badly hit by the 1998 Russian financial crisis.

Crucially, there were favourable domestic conditions to promote a European orientation. According to a survey conducted in the first half of 2000, 60 per cent of the Moldovan population had a very, or fairly, positive attitude towards the EU as opposed to 6 per cent against. However, only one-third thought of themselves as 'Europeans'. The vast majority underlined the importance of good relations with Russia. Finally, respondents mentioned economic development and political stability as dominant benefits of Moldova's EU membership (White et al., 2001: 293-296). Most political parties wanted Moldova to integrate, or at least develop relations, with the EU but pro-European slogans were not initially evident during election campaigns. A cross-party pro-European declaration was published in June 2000 (Klipii, 2002: 27-30). Although the signature of the biggest parliamentary party - the Communists (PCRM) - was missing, it did not oppose this EU direction (Löwenhardt et al., 2001: 618).

Despite considerable support for Moldova's integration with the EU, elites and society had little understanding of all the implications of such an orientation. Supporting Moldovan elites seemed to perceive it as a foreign policy choice and membership of an international club rather than as a task to include taking far-reaching domestic reforms. As a result, the proEuropean narrative was rarely followed up by actions (Shapovalova and Boonstra, 2012: 54$55)$.

The EU, in its turn, was initially reluctant to enhance relations with Moldova because it was perceived as a politically and economically unstable country, affected by the Transnistrian conflict and dominated by Russia. A further discouraging factor was initially Moldova's seemingly inconsistent foreign and domestic policies. Moreover, the EU was preoccupied with other problems such as conflicts in the Western Balkans, enlargement to Central and Eastern Europe and, during the 1990s, establishing itself as a foreign policy actor (Shapovalova and Boonstra, 2012: 51-55).

\section{The 2000s: the new neighbours}

The 2000s brought important changes to relations between Moldova and the EU. First, ahead of the 2004 Eastern enlargement, the EU decided to develop a comprehensive policy toward 
its southern and new Eastern neighbours. This included Moldova, directly bordering the EU since 2007 when Romania became a member. While Moldova had little economic importance, it became a potential source of security threats and a challenge for EU border integrity. As a weak state with a frozen conflict on its soil, Moldova could be seen, with reference to the 2003 European Security Strategy, as a troubled place located on the EU's borders. In order to enhance its security, Brussels set itself the task of promoting a ring of stability, consisting of democratic and prosperous countries in the neighbourhood. Crucially, however, membership was not on offer (Ratzmann, 2012).

During this period, Moldova experienced significant change. The PCRM achieved a supermajority in the legislature after the February 2001 elections and in a parliamentary vote its leader - Vladimir Voronin - was chosen as the Moldovan President, taking all power in the country. Despite election slogans about joining the Russia-Belarus Union, anti-European rhetoric, some democratic reversals, and enhancing relations with Russia after taking power, the Communist government did not turn their back on the EU. In June 2001 Moldova joined as the only post-Soviet country - the Stability Pact for South Eastern Europe. The 2002 draft of the foreign policy platform declared European integration as a strategic objective of Moldova (Infotag, 2002), while in 2003 the Concept for the Integration of the Republic of Moldova in the EU was further elaborated. In addition, during this period some domestic institutions to support Moldovan-EU interaction were set up.

In 2003, the European Commission adopted a communication entitled 'Wider Europe Neighbourhood: A New Framework for Relations with our Eastern and Southern Neighbours', the foundations of the 2004 European Neighbourhood Policy (ENP). In these circumstances Moldova's relationship with Russia became more problematic. Initially, the Moldovan authorities were disappointed with this initiative because it did not offer the prospect of membership and linked countries with disparate backgrounds and objectives towards the EU. In the end, Moldova finally decided to join the ENP.

The Communists held on to power in the 2005 elections but in the midst of what came to be called 'an orange evolution' (March and Herd, 2006). The PCRM government declared their full commitment to further European integration and the newly elected parliament adopted a declaration of political partnership to achieve the objectives of greater European integration. All parties signed the ENP Action Plan. Moreover, the EU appointed a Special Representative for Moldova dealing mainly with the Transnistrian problem and, together with the United States, joined negotiations on resolution of the conflict as an observer. Finally, the European Commission opened its delegation in Chisinau and deployed the EU Border 
Assistance Mission to Moldova and Ukraine (EUBAM) to the Ukrainian-Moldovan border, including its Transnistrian section.

The PCRM showed an increasing inclination towards authoritarianism, being classified by the Freedom House (2010) as a semi-consolidated authoritarian regime in 2005 and also in 2008-10 (with their most critical concerns regarding media freedom and electoral fraud). However, further integration with the EU was still among Moldova's priorities. The EU granted Moldova trade preferences: GSP+ (Generalised System of Preferences) in 2006 and then ATPs (Autonomous Trade Preferences) in 2008. An EU Common Visa Application Centre was established in Chisinau in 2007, while the following year the parties signed visa facilitation and readmission agreements and a Mobility Partnership facilitating legal migration of Moldovans.

In 2006, together with the Western Balkans group, Moldova joined the South East European Cooperation Process (SEECP). The PCRM was, however, critical of the Eastern Partnership (EaP) initiative which became an official EU programme in 2009. It was aimed at assisting new neighbourhood states from Eastern Europe and the Caucasus in the hope of binding them closer to the EU. Moldova sought a deeper Association Agreement which stipulated EU membership. The EU indicated its readiness to consider a new and deeper agreement including free trade and visa liberalisation but with the PCRM under strict conditionality of conducting transparent and fair elections in 2009 (Shapovalova and Boonstra, 2012: 55-62).

Several factors explain the Communist government's pursuit of a pro-European orientation. The first was related to geopolitics. Owing to Moldova's location in a contested neighbourhood, the PCRM could oscillate between the EU and Russia and played on the differences between them for their own benefits (Korosteleva, 2010; Weiner, 2004). It was anticipated that the EU was afraid to be too critical of communist policies, for fear of driving Moldova towards the Russian sphere. Furthermore, more committed engagement by the EU in its Eastern neighbourhood allowed Moldova to potentially balance the excessive influence of Russia much more effectively than in the 1990s (Cantir and Kennedy, 2015). The result of this somewhat delicate balancing act was a gradual worsening relationship with Russia in 2003-6. However, the EU did not want to provoke a geopolitical confrontation with Russia and it withheld fulsome support for Moldova. As a result, the PCRM moved to re-enhance its relations with Russia in 2006.

The second motive behind the pro-European course taken by the PCRM was internal: they wished to secure electoral popularity and remain in power. As in the 2001 parliamentary 
election, foreign policy formed a significant part of the Second Plan, receiving much more attention in following elections. The popularity of EU membership oscillated between 57 and 76 per cent in the 2000s (Institutul de Politici Publice, 2015: 97). But at the same time, many Moldovan voters appreciated keeping good relations with Russia (Korosteleva, 2010: 12811282). A positive EU outlook was electorally vital when examining voter motivation: economic prosperity (57 per cent), freedom of movement (38 per cent), democracy (32 per cent) and stability (30 per cent), as a 2008 survey showed. Additionally, a majority of respondents believed they had much in common with Europeans (Korosteleva, 2010: 1281).

The pro-EU platform of the Communist Party adopted in the February 2005 parliamentary election undermined the opposition campaign which was not able to use European slogans exclusively for its own benefit. In the aftermath of the election it also assisted in achieving the necessary parliamentary support - including from their arch-rival, the Christian-Democratic People's Party - to elect Voronin for a second term as President (Kennedy, 2010). The benefits of the pro-EU platform were also evident in 2009, Before, during and after the April 2009 crisis - triggered by alleged fraud in the April 2009 parliamentary elections and street protests in Chisinau violently suppressed by the police - the ruling communists generally got support from the EU in the name of retaining political stability in Moldova and keeping Moldova on its Europeanisation course. For example, the EU tried to convince the opposition to provide the communists with one more vote in the parliament needed to elect a president (Raik and Dinesen, 2015; Tudoroiu, 2011: 301-304). However, the opposition did not accept this and following the dissolution of Parliament, the communists lost power in the snap parliamentary elections of July 2009.

A third motivation for the promotion of an EU orientation concerned boosting the Moldovan economy and the general modernisation of the country. Put simply, the PCRM could not ignore the fact of the increasing share of EU-Moldova external trade and increasing amount of transfers from Moldovans working in the EU. A major effort was made to diversify Moldova's traditionally CIS-oriented exports into new EU markets. This became especially important when Russia - in punishing Moldova for tightening relations with the West imposed sanctions on the import of the main Moldovan export products (wine, fruits, vegetables, and meat) between 2005 and 2006, a serious hit to the already shaky Moldovan economy. Moldovan exports to the EU increased from 32.3 per cent in 2001 to 52.0 per cent in 2009, while exports to the CIS decreased from 60.9 per cent to 38.2 per cent (National Bureau of Statistics of the Republic of Moldova, 2014). 
Furthermore, European sources of assistance grew considerably. The EU granted Moldova $€ 173.0$ million between 2000 and 2006, mainly under the Technical Assistance for the Commonwealth of Independent States (TACIS) and the Food Security Program. In 2007, the European Neighbourhood and Partnership Instrument (ENPI) became the main source of European aid to Moldova. It envisaged €209.7 million for Moldova till 2010. Through budgetary support and technical assistance, the ENPI aimed to support: democracy development and good governance, regulatory reform and administrative capacity building, and poverty reduction and economic growth (Boian, 2010). Importantly, Moldova became the second greatest recipient of EU assistance per capita after the Palestinian territories. On the other hand, Russian sanctions on Moldova could not be completely discounted and needed a response to mitigate their impact.

The final factor behind the choice of an EU pathway by the Communist government was the resolution of the Transnistrian conflict. Initially, it was believed that Russia would be a major player in its resolution. Indeed, Russia presented its own plan, the Kozak Memorandum secretly negotiated with Moldova and Transnistria independently of other international actors. However, it was dismissed by President Voronin shortly before the signing ceremony in November 2003 under Western and domestic pressure and because of the inclusion in the text of a regulation allowing Russian troops to stay in Moldova until 2020 on which there had allegedly been no consultation. As a result, relations with Russia worsened and Moldova turned westward for a diplomatic solution. The conflict in Moldova had already developed an EU dimension. Apart from its formal role in ongoing negotiations for conflict resolution, the EU engaged in low-profile confidence building between conflicting parties, supporting border management, curbing the scale of cross-border smuggling, facilitating Transnistria's legal trade within Moldova's economic space, and in general fostering peopleto-people contacts. However, the EU's involvement was in the background and piecemeal to avoid antagonising Russia (Popescu, 2010: 38-65). This approach was inevitably disappointing for the Moldovan government.

For the most part Europeanisation was mainly perceived by the communist government in geopolitical terms. They did not associate the necessary corollary of a deep EU relationship with considerable internal reform. Some progress was made in the establishment of institutional frameworks and the approximation of domestic legislation to EU standards but the implementation of reforms was poor, especially with regard to judicial reform, fighting corruption and media freedom. If these reforms had been progressed, the implication for the PCRM would have been a commensurate loss of its power base that remained dependent on 
patronage and partiality. Additionally, lack of clear EU membership prospects and Russia's punitive sanctions policy were conflicting and discouraging factors. However, in the case of issues of pressing importance to the PCRM, namely trade and freedom of movement with the EU, they were ready to implement reforms. Crucially, the EU found this beneficial too and was ready to assist Moldova with a policy of 'credible conditionality', that is to offer tangible benefits (such as wider access to European markets) in return for limited but real reforms. Similarly, on some other issues such as development assistance and the Transnistrian conflict, where the preferences of both parties converged there existed a mutual incentive to cooperate successfully (Bosse, 2010: 1306-1307; Hagemann, 2013).

\section{The 2010s: the partners?}

With the failure of the PCRM in Moldova's parliamentary elections of 29 July 2009, a new chapter in relations between Moldova and the European Union opened. On 8 August 2009, the openly pro-European election winners - the Liberal Democratic Party of Moldova (PLDM), the Democratic Party of Moldova (PDM), the Liberal Party (PL) and the 'Our Moldova' Alliance - agreed to create a ruling coalition. According to the coalition agreement, the key priorities for foreign policy were to integrate with the EU and, in particular, to sign an Association Agreement (Declaratie privind constituirea, 2009). On 25 September, the Alliance voted in a pro-European government led by Vlad Filat, which on 1 December adopted a new, four-year activity programme European Integration: Freedom, Democracy, Welfare (Programul de activitate al Guvernului Republicii Moldova, 2009). The programme clearly stated that the new government saw Moldova's integration with the EU as a 'fundamental priority of the domestic and foreign policies of the Republic of Moldova'. The document also stressed that Europeanisation was 'the most efficient way to achieve political, economic and social modernization of the country'. The programme underlined Moldova's willingness to sign an Association Agreement with the EU and its wish to join the Union in the foreseeable future. Although subsequently, as a result of political crises and elections, the name of the coalition, its members and leadership has changed, since 2009 the country has been ruled by the same political elite.

\section{Moldovan governments and the EU holy grail}


There were four reasons behind the choice of European integration as an ideological base and political leitmotif of the pro-European parties in Moldova. No doubt, one of the most important was that the pro-European agenda could secure the support of the pro-European voters, a significant part of Moldovan society. Presenting itself as pro-European was important to the coalition parties for subsequent parliamentary elections in November 2010 and, especially, November 2014. In the latter election, despite a number of corruption scandals, pro-European parties could still attract a large section of voters who welcomed proEuropean slogans even though coalition credibility had declined. This was possible because leaders of pro-European parties managed to convince the majority of Moldovan people that even with a parallel minority upsurge of pro-Russian political sympathy for an Eastern integration with the (then) Eurasian Customs Union (ECU), a vote for the government coalition was in fact a sounder geopolitical choice and the only way to keep Moldova on a modernising track (Socor, 2014), Even now when support for EU integration in Moldova is falling, authorities maintain a pro-European rhetoric because it allows them to sustain this core pro-European electorate. To change this geopolitical orientation would indicate unreliability and indecision from the perspective of many voters and could risk a catastrophic drop in core electoral support.

The second political driver towards an EU future was a desire to curb Russian influences in Moldova and ultimately to separate from the Russian sphere of influence. Gaining independence from Moscow was perceived by Chisinau as a chance to obtain more presence on the international stage. It was also a straightforward and popular stance - a cultural and historical 'return to Europe' at least among Romanian and pro-European electorates.

Third, cooperation with the EU promised faster development of the country by drawing in new investment; creating employment and new production technologies and thus modernising the existing industrial base. Better access to European aid programmes and loans, and getting wider access to the European markets which traditionally accounts for about half of Moldovan external trade, were part of a logic of modernity.

In 2011, the coalition partners started preliminary talks with EU officials on the Association Agreement, including (what was to be the most important aspect in the short term) a Deep and Comprehensive Free Trade Area (DCFTA) (Second Joint Progress Report, 2011). This would shrink their Russian dependence and minimise future political pressures from the Kremlin (in the shape of embargos or the cancellation of investments). Another 
important step by Moldovan authorities was to join the Energy Community in 2010. The contracting parties are committed to ownership unbundling in the field of energy which means splitting the generation of electricity from its transmission to a distribution system operator or to the consumer.

Fourth, it was hoped that a firm rapprochement with the EU would help towards a settlement of the Transnistrian separatism issue. The anticipated outcome of integration (i.e. improved economic conditions and evident modernisation) was meant to also become a tempting perspective for Transnistrian society and elites. The coalition hoped it could lead to stronger political and economic cooperation.

\section{The European Union and its members: perspectives}

The EU greeted the new, 2009, pro-European Moldovan government with clear satisfaction. Within the next few months, the EU's engagement in the country increased significantly. It was also boosted by the launch of the Eastern Partnership in May 2009. In January 2010, the EU agreed to negotiations for an Association Agreement and in June 2010 Moldova and the EU began talks on granting Moldovan citizens visa-free access to the Schengen area for 90 days. The EU also offered Moldova concrete and increasing financial support to implement necessary key reforms. Between 2010 and 2013, Moldova gained $€ 550$ million in assistance. In 2014, the EU supported Moldova with more than $€ 130$ million (Delegation of the European Union to Moldova, 2015; European Commission, 2014). Since 2010, EU political advisers have also been assigned to help Moldovan state reform and observe the work of Moldovan public institutions (Delegation of the European Union to Moldova, 2010).

From the perspective of Brussels, involvement in Moldova was mostly aimed at providing stability beyond the new EU borders, especially in the context of Transnistria (Dias, 2013). Pro-European Moldova was expected to become a more transparent and predictable partner. For example, by granting Moldova a visa-free regime to the Schengen zone, the EU forced the Moldovan government to seal its borders, reform the state border guard service, bolster control of the Transnistrian border and introduce biometric passports and an automated passport control system. The aspiration of the EU was to turn Moldova into a model state within the Eastern Partnership which could be a positive example to other EaP countries like Ukraine. However, as with other EaP members, the EU was not interested in 
offering Moldova any clear prospect of future membership. This was reflected in the content of the Association Agreement, eventually signed by Moldova in June 2014.

Moldova's integration with the EU was particularly important to two EU member states: Romania and Germany. From Romania's perspective, Moldova's rapprochement with the EU was a chance to repair mutual relations which had suffered during the Soviet era, by extending economic and cultural cooperation, securing its eastern border and pulling Moldova away from a Russian sphere of influence (thus moving Russia further away from Romania's borders). Romanian-Moldovan relations intensified as soon as the pro-European coalition was formed in Chisinau. Romania tried to exploit the European aspirations of the new Moldovan government by becoming Moldova's main advocate in the EU. By creating a platform of cooperation to allow EU states to build friendly bilateral relations, Romania sought to enhance its position within the EU. A good example of such activity is the creation of the Friends of Moldova Group in cooperation with France.

From Germany's perspective, European integration of Moldova was seen as a helpful tool in the implementation of crucial elements of German foreign policy: improvement of EU border security, control of migration and the resolution of the Transnistrian conflict. Moldova was also the litmus test for Russia's reaction to further EU enlargement to the east. Germany's interest in Moldovan affairs has been increasing since 2009 when a German was appointed the head of the EU delegation in Chisinau and head of the EUBAM to Moldova and Ukraine.

The EU offered the pro-European coalition in Chisinau almost unconditional support, refraining from open criticism of the Moldovan authorities despite evident examples of corrupt, unlawful or undemocratic practice. The EU was concerned not to contribute to any decline in internal support for the government that might result in the return of more proRussian parties to power.

Only a few months after the pro-European coalition was established, the EU had already labelled Moldova as a 'success story' of the Eastern Partnership. Negotiations on the content of agreements such as the DCFTA were making rapid progress, especially in contrast to Ukraine. Moldovan citizens were the first citizens of a post-Soviet state (except the Baltic states) to enter a visa-free regime for the Schengen zone.

This positive evaluation of Moldova by Brussels lasted until the beginning of 2013 when the Filat government collapsed as a result of a political crisis (Całus, 2013). This revealed the extremely high levels of corruption among the Moldovan ruling elite. For a substantial part of Moldovan society, in the last few years Moldova has become the 'captured 
state' in which public institutions are subordinated to local politicians and oligarchs (Całus, 2014; Tudoroiu, 2014). It became clear that Moldovan politicians were interested in securing their own private businesses, rather than focusing on the modernisation of the country. In spite of the EU's growing disappointment with Moldova, the country managed to initial and eventually sign the Association Agreement (in November 2013 and in June 2014, respectively). EU officials noted, however, that in spite of the narrative of Moldovan government officials and the formal enactment of several laws, key reforms (especially judicial reform, decentralisation and financial sector reform) were either not implemented or their progress was very slow. The EU did not criticise Moldova openly prior to the elections in November 2014. However, the EU changed its attitude at the end of 2014. It was concerned not only with the moderate success of pro-European forces in Moldova but also with the scandalous behaviour of two main coalition partners - PLDM and PDM - during elections. Abuses in the election process and inability to form a government during the following three months opened the way for a highly critical Commission Progress Report on Moldova (European Commission, 2015).

\section{Moldovan popular opinion and the EU}

Popular attitudes towards European integration have clearly evolved in recent years of rule by the pro-European coalition. To Moldovans, rapprochement with the EU still predominantly means the opportunity to improve living conditions, legal permission to work abroad and increasing stability. These expectations are the result of a somewhat idealised picture of the EU created by pro-European political parties, and by nearly 300,000 Moldovan migrants working in the EU. The message that has been sent to people is that the EU is a remedy for all the country's problems. However, paradoxically, the establishment of overtly pro-European governments coincided with a deterioration in the level of support for the European idea and European integration among Moldovans. As a result, in March 2015 support for European integration declined to 40 per cent (Institutul de Politici Publice, 2015: 97). This has been a consequence of two factors.

The first - and most important - factor was the establishment of the ECU by Russia in January 2010, seen as a tangible alternative to the EU. The idea of rapprochement with the then ECU (and later, from 1 January 2015, Eurasian Economic Union - EEU) has canalised pro-Russian sentiments for some parts of Moldovan society. It was additionally fuelled by 
active promotion of this organisation in Moldova by Russia and pro-Russian political forces (including the PCRM which has promoted integration with the ECU/EEU since 2011). The ECU/EEU was presented as an organisation similar to the EU, based on the European integration model but, at the same time, more modern and more resistant to economic disruptions (the economic crisis that hit Europe seemed to have bypassed Russia). The Russian-led economic integration project was also pictured as an organisation more adjusted to Moldova in terms of religion and culture. Eastern Orthodoxy - unlike in the EU - is the dominant religion in the EEU: more than 80 per cent of Moldovans are members of the Moldovan Orthodox Church which is subordinated to the Russian Orthodox Church. Member states of this organisation are also presented as more conservative in terms of values (e.g. negative attitudes toward sexual minorities), fitting the traditional conservatism of Moldovan society (Barbarosie, 2015).

Propaganda promoting the ECU/EEU intensively exploited sentiment toward the Soviet past still present among a large number of Moldovan citizens. It also highlighted cultural affinities between the member states and Moldova which derive from the long-term experience of common statehood (from 1812 until 1918 within the Russian Empire and from 1944 until 1991 within the Soviet Union). A pro-ECU/EEU narrative strongly focused on the prospect of immediate economic benefits: guaranteed access to the Russian market, migration opportunities (as of 2014, between 300,000 and 350,000 Moldovans work in Russia), and a long-term contract for cheap gas deliveries, and so on (Cepoi, 2014). The establishment of the ECU was thus a factor in the significant public decline in EU support with sections of Moldovan society increasingly perceiving the EU as an organisation promoting abstract ideas and values, unlike the Russian-led project which was seen as a pragmatic, international organisation oriented towards economic opportunity.

Transformation of the ECU into the EEU remained virtually unnoticed by the overwhelming majority of the Moldovan public, which perceives it as practically the same organisation. Therefore, it did not influence the level of support for the Russian integration project among Moldovans. It is interesting that even the outbreak of the Russian-Ukrainian conflict in February 2014 did not really change their attitude toward the ECU. In March 2015, the idea of Eurasian integration was supported by 58 per cent of Moldovans (Institutul de Politici Publice, 2015: 97).

A second reason for this decline in support for the EU has been the negative stereotyping of the EU that has spread as part of a campaign promoting the ECU/EEU, and which is particularly visible in the Russian media popular in Moldova. Pro-Russian parties 
(such as the PCRM and the Party of Socialists) also launched a campaign aimed at discrediting the EU with certain myths and false rumours. Since knowledge of the EU by Moldovans is low, many accept negative stereotypes as the truth. The EU did little to counter this: the Delegation of the European Union to Moldova has not provided a consistent or broad-based information campaign which could counter Russian propaganda. The result is that many Moldovans concluded that Moldova's accession in the EU will mean the loss of a new independence; by others it is perceived as part of the government's hidden agenda to reunite with Romania. Such a perception is particularly popular among national minorities, for example Gagauzians (Totul, 2014).

Another further disappointment with the ruling pro-EU elite is that despite its European reformism it has failed to reduce levels of corruption. Neither has there been tangible economic improvement which is evidently visible to Moldovan citizens. Massive corruption scandals involving pro-European elites have played their part in undermining the legitimacy of government and thus its manifesto for an EU future. Moreover, the attitudes of EU politicians and officials seen supporting the Moldovan government, no matter what it was doing in the country, did not meet with warm reactions in Moldova. Some Moldovan opposition politicians and experts have also criticised the EU; that by refraining from criticism, the EU has slowed down reforms and encouraged corruption (Noi, 2015). Although the Moldovan electorate has been regularly informed about the stream of European financial aid coming to Moldova - the highest rate per capita among all the Eastern Partnership states (Central European Policy Institute, 2013) - this has hardly been visible in public opinion. Since there seems to be no tangible public impact, with a considerable amount of EU aid being spent on institution building, a critical public has accused politicians of stealing European money.

\section{A balance of cooperation}

Six years of rule by a pro-European coalition has certainly brought Moldova closer to the EU. The country's greatest successes in this period were ultimately the signing of an Association Agreement (including the DCFTA) and the liberalisation of the visa regime. Successive governments have kept Moldova on a pro-EU course despite strong political and economic pressure from Moscow (including trade embargoes and energy blackmail). The EU has provided substantial financial and technical assistance to Moldova, whose governments have 
attempted to process some of these EU conditionalities. However, many reforms have not been implemented, even though they have been legally adopted. Those most likely to be implemented are reforms that offer no threat to the large political-business interests of the ruling elite or likely to be immediately popular and therefore vote catching. This is why Moldova has moved so quickly to obtain the visa-free regime status and sign the symbolically significant Association Agreement. But reforms of the judicial system (overseen by Vlad Plahotniuc, a sponsor and de facto leader of PDM) and the financial sector (policed by Vlad Filat) have failed. It could be claimed that the EU, having weighed up the political disadvantages of negative consequences from the possible overthrow of pro-European coalitions, has ducked away from any serious attempt at Moldovan EU-isation in the near future.

\section{Conclusion}

Despite the steady intensification of relations between Moldova and the EU, in the twentyfirst century they have been plagued by significant problems. One is that the priorities of Moldovan governments and population, and the EU, do not coincide. The Moldovan government has a principal aim of EU accession, while the EU is not ready to offer them any clear perspective for membership. Furthermore, the priority for Moldovan political elites has been to maintain power. This has encouraged successive governments to use pro-European rhetoric and implement some EU originating reforms for electoral purposes. However, a desire to stay in power has simultaneously prevented the introduction of many other EU required reforms, especially with regard to the judiciary and curbing corruption.

With regard to the external pressures from the EU, these have been shaped to sustain internal regime stability. On the one hand, it has offered financial support for Moldova's development and assistance to reforms. On the other hand, it has sought to avoid political confrontation with Russia, which opposes Moldova's integration with the EU, and offered relatively uncritical support for the Moldovan authorities, regardless of the real merits in progressing towards EU-isation.

Finally, the Moldovan population, which for some time was strongly Euroenthusiastic, initially associated European integration with improvement in its socio-economic future. Failures by the present government to curb corruption and provide tangible economic change along with the appearance of an alternative - the Russian-led integration project - 
have led more recently to a considerable decrease in public support for Moldova's accession to the EU.

However, the fact that ruling 'pro-EU' parties have lost so much of the trust and support of their electorates does not mean that the idea of European integration is no longer tempting for Moldovan society. A European ideal - when preached by popular political forces - can still attract the interest of the electorate, and sustain noticeable support. At the same time, while the Russian-Ukrainian conflict has not impacted visibly on the EU policy toward Moldova, the unpopular actions of the Moldovan political elite did. The EU has finally acknowledged that Moldova can hardly be considered a 'success story' of the Eastern Partnership. From the end of 2014 and through to 2015, the perception of Moldovan authorities by the EU and trust in their desire to truly reform the country deteriorated dramatically. It became clear that the pro-European ruling elite is corrupt and is mostly focused on an internal battle for control over state institutions and financial flows. In consequence, the EU has ceased its ostensibly open support for the Moldovan government and instead has started to promote the pro-EU idea rather than specific pro-EU parties. This step - if connected with an effective EU information policy on the benefits of European integration directed to Moldovan society - may gradually restore dwindling public trust in a Moldovan future within the EU.

\section{References}

Dias, V.A. (2013). The EU's post-liberal approach to peace: framing EUBAM's contribution to the Moldova-Transnistria conflict transformation. European Security, 22(3), 338354. doi: 10.1080/09662839.2012.712039

Barbarosie, A. (2015). Unprecedented decrease in the support for the European integration. Causes and consequences (interview with Lina Grâu). Synthesis and Foreign Policy Debates, 3, 2-4.

Boian, V. (2010). Taking Stock and Evaluation of Financial Assistance Granted to Moldova by the European Union. Chisinau: APE.

Bosse, G. (2010). The EU's Relations with Moldova: Governance, Partnership or Ignorance? Europe-Asia Studies, 62(8), 1291-1309. doi:10.1080/09668136.2010.504528

Całus, K. (2013, March 14), Vlad Filat: A vote of no confidence in Moldova. New Eastern Europe. Retrieved from http://www.neweasterneurope.eu/component/content/article/ 20-eastern-europe-50/621-vlad-filat-a-vote-of-no-confidence-in-moldova 
Całus, K. (2014, April 22). A captured state? Moldova's uncertain prospects for modernization. OSW Commentary. Retrieved from http://www.osw.waw.pl/sites/ default/files/commentary_168_0.pdf

Cantir, C., \& Kennedy, R. (2015). Balancing on the Shoulders of Giants: Moldova's Foreign Policy toward Russia and the European Union. Foreign Policy Analysis, 11(4), 397416. doi:10.1111/fpa.12051

Central European Policy Institute. (2013). 2nd Moldova Reality Check: Success Story Before the Storm? Retrieved from http://www.cepolicy.org/publications/2nd-moldova-realitycheck-success-story-storm

Cepoi, M. (2014). Informarea societății moldovenești privind procesul de integrare europeană: între acțiuni întârziate și manipulare. Chisinau: IDIS "Viitorul".

Chirila, V. (2002). The relations between the Republic of Moldova and the European Union. In A. Barbăroșie \& V. Gheorghiu (Eds.), The Republic of Moldova and the European integration (pp. 37-67). Chișinău: Cartier.

Conceptyia politicii externe a Republicii Moldova. (1995). Retrieved from http://lex.justice.md/viewdoc.php?action=view\&view=doc\&id=306955\&lang=1

Declaraţie privind constituirea Coaliţiei de guvernare 'Alianţa pentru Integrarea Europeană'. (2009). Retrieved from http://www.edemocracy.md/parties/docs/joint/200908081/

Delegation of the European Union to Moldova. (2010). The EU high level policy advisors were officially presented. Retrieved from http://eeas.europa.eu/delegations/moldova/press_corner/all_news/news/2010/2010042 2_01_en.htm

Delegation of the European Union to Moldova. (2015). EU-Moldova Relations: Deliverables. Retrieved from http://eeas.europa.eu/delegations/moldova/eu_moldova/political_relations/eu_moldova _relations_deliverables/index_en.htm

European Commission. (2014). European Union supports key reforms in the Republic of Moldova. Retrieved from http://europa.eu/rapid/press-release_IP-14-886_en.htm

European Commission. (2015, March). ENP Country Progress Report 2014 - Republic of Moldova. Retrieved from http://europa.eu/rapid/press-release_MEMO-154682_en.htm

Freedom House. (2010). Nations in Transit: Moldova. Retrieved from https://freedomhouse.org/report/nations-transit/2010/moldova

Hagemann, C. (2013). External Governance on the Terms of the Partner?: The EU, Russia and the Republic of Moldova in the European Neighbourhood Policy. Journal of European Integration, 35(7), 767-783. doi:10.1080/07036337.2012.732073

Infotag (2002, May 1). Proyekt kontseptsii vneshney politiki Moldovy opredelyaet evropeyskuyu integratsiyu v kachestve prioritetnoy zadachi. Retrieved from http://press.try.md/item.php?id=15523

Institutul de Politici Publice. (2015, April). Barometrul Opiniei Publice: Dinamica răspunsurilor (aprilie 2003-martie 2015). Retrieved from http://ipp.md/public/files/Barometru/BOP_04.2015_anexa.pdf 
Kennedy, R. (2010). Moldova. In D. Ó Beacháin \& A. Polese (Eds.), The colour revolutions in the former Soviet republics. Successes and failures. London: Routledge.

Klipii, I. (2002). Evolution of political framework of the European Integration problem. In A. Barbăroșie \& V. Gheorghiu (Eds.), The Republic of Moldova and the European integration (pp. 9-36). Chișinău: Cartier.

Korosteleva, E. (2010). Moldova's European Choice: 'Between Two Stools'? Europe-Asia Studies, 62(8), 1267-1289. doi:10.1080/09668136.2010.504383

Löwenhardt, J., Hill, R. J., \& Light, M. (2001). A wider Europe: The view from Minsk and Chisinau. International Affairs, 77(3), 605-620. doi:10.1111/1468-2346.00209

March, L., \& Herd, G. (2006). Moldova Between Europe and Russia: Inoculating Against the Colored Contagion? Post-Soviet Affairs, 22(4), 349-379. doi:10.2747/1060586X.22.4.349

National Bureau of Statistics of the Republic of Moldova. (2014). External Trade of the Republic of Moldova (1997-2013). Retrieved from http://www.statistica.md/public/files/serii_de_timp/comert_exterior/serii_anuale/eng/C om_Ext_RM.xls

Noi (2015, 5 May). Sotsialisty: V situatsii v Moldove vinovaty Evrosoyuz i SShA. Retrieved from http://www.noi.md/ru/news_id/60513

Popescu, N. (2010). EU foreign policy and post-Soviet conflicts: Stealth intervention. London: Routledge.

Programul de activitate al Guvernului Republicii Moldova 'Integrarea Europeană: Libertate, Democraţie, Bunăstare' 2009-2013. (2009). Retrieved from http://www.ungaria.mfa.md/img/docs/programul-activitate-guvernului.pdf

Raik, K., \& Dinesen, R. L. (2015). The European Union and Upheavals in its Neighborhood: A Force for Stability? International Journal of Public Administration, 38(12), 902914. doi:10.1080/01900692.2015.1015550

Ratzmann, N. (2012). Securitizing or developing the European neighbourhood?: Migration management in Moldova. Southeast European and Black Sea Studies, 12(2), 261-280. doi:10.1080/14683857.2012.686188

Second Joint Progress Report: Negotiations on the EU-Republic of Moldova Association Agreement, Chisinau. (2011, April 11). Retrieved from http://eeas.europa.eu/moldova/docs/2011_05_aa_joint_progress_report2_en.pdf

Socor, V. (2014). Moldova's Parliamentary Elections: European Choice Versus Russian Political Projects (Part One), Eurasia Daily Monitor, 11(214), Retrieved from http://www.jamestown.org/regions/europe/single/?tx_ttnews\%5Btt_news\%5D=43136 \&tx_ttnews\%5BbackPid\%5D=51\&cHash=fb1f0d85205ca824ea87687564227dbc\#.V Ww8rc-qhHw

Shapovalova, N., \& Boonstra, J. (2012). The European Union: From Ignorance to a Privileged Partnership with Moldova. In M. Kosienkowski \& W. Schreiber (Eds.), Moldova. Arena of International Influences (pp. 51-75). Lanham, Md: Lexington Books.

Totul (2014, 5 August). OPROS: Gagauzy schitayut, chto evrointegratsiya oznachayet ob"yedineniye Moldovy s Rumyniyey. Retrieved from http://totul.md/ru/newsitem/537142.html 
Tudoroiu, T. (2011). Communism for the Twenty-first Century: The Moldovan Experiment. Journal of Communist Studies and Transition Politics, 27(2), 291-321. doi:10.1080/13523279.2011.564101

Tudoroiu T. (2014). Democracy and state capture in Moldova. Democratization, 22(4), 655678. doi:10.1080/13510347.2013.868438

Ungureanu, O. (2002). Stability Pact for South-Eastern Europe and perspectives for the Republic of Moldova's inclusion. In A. Barbăroșie \& V. Gheorghiu (Eds.), The Republic of Moldova and the European integration (pp. 68-79). Chișinău: Cartier.

Weiner, R. (2004). The Foreign Policy of the Voronin Administration. Demokratizatsiya, 12(4), 541-556.

White, S., Light, M., \& Lowenhardt, J. (2001). Belarus, Moldova and Ukraine: Looking east or looking west? Perspectives on European Politics and Society, 2(2), 289-304. doi:10.1080/1570585018458763 